\title{
ANALISIS PEMANFAATAN DATA KUALITAS PERAIRAN UNTUK PERENCANAAN ZONASI PESISIR
}

\author{
THE ANALYSIS OF WATER QUALITY DATA UTILIZATION FOR COASTAL ZONE PLANNING
}

\author{
Handy Chandra'), Domu Simbolon'), Budy Wiryawan²), Budhi H. Iskandar²), Am Azbas \\ Taurusman'2). \\ ${ }^{1)}$ Pusat Penelitian dan Pengembangan Sumberdaya Laut dan Pesisir (P3SDLP) \\ Badan Penelitian dan Pengembangan KP, KKP. Jl. Pasir Putih 2, Ancol, 14430, Indonesia \\ e-mail: handavin@gmail.com \\ ${ }^{2)}$ Departemen Pemanfaatan Sumberdaya Perikanan (PSP) - FPIK, Institut Pertanian Bogor
}

Diterima tanggal :8 Desember 2016, diterima setelah perbaikan: 17 Desember 2016, disetujui tanggal:24 Desember 2016.

\begin{abstract}
ABSTRAK
Perairan pesisir pulau Wangi-wangi di kabupaten Wakatobi, Sulawesi Tenggara telah mengalami tekanan aktifitas manusia (antropogenik) sejak menjadi kabupaten baru tahun 2003. Tekanan antropogenik diukur menggunakan parameter kualitas air (suhu dan oksigen terlarut). Tujuan riset ini adalah menganalisis pemanfaatan data pemonitoran waktu serial dan pemanfaatannya untuk perencanaan zonasi perairan, yang dikaitkan dengan data parameter kualitas air. Dinamika perairan pesisir telah terjadi pada musim angin timur dan barat, pada kedalaman 5 meter dan 25 meter. Hasil menunjukkan kegunaan data waktu serial untuk dinamika zonasi perairan pesisir. Bagian timur dan utara perairan direkomendasikan untuk zona konservasi, sementara zona pemanfaatan lainnya dialokasikan buat sub-zona perikanan berkelanjutan (rumput laut)
\end{abstract}

Kata kunci: zona, data waktu serial, parameter kualitas air, oksigen terlarut

\section{ABSTRACT}

The coastal waters of Wangi-wangi Island in Wakatobi regency, Sulawesi Tenggara province had been under high anthropogenic pressure since 2003. Anthropogenic pressure measured by water quality parameters (temperature and dissolved oxygen). The aim of this research was to study utilization of time series data monitoring in coastal waters (related to water quality data) for marine spatial planning. Coastal water dynamics was happened on west and east monsoon in $5 \mathrm{~m}$ and $25 \mathrm{~m}$ depth. Hypoxic and anoxic conditions were happened in $25 \mathrm{~m}$ depth. Result shows useability of time series data for dynamic coastal water spatial/zone planning. Western and southern coastal water zones were recommended for economic activity. Eastern and northern coastal water zones were recommended for conservation zone while other utilization zone has been allocated for sustainable fishing sub-zone.

Keywords: zone, time series data, water quality parameter, dissolved oxygen

\section{PENDAHULUAN}

Tekanan aktifitas ekonomi yang semakin tinggi dan terjadi di kawasan perairan pesisir, makin menunjukkan perlunya pengelolaan memakai model atau mekanisme zonasi secara terintegrasi (secara internasional disebut sebagai Marine Spatial Planning atau disingkat MSP), karena pengelolaan dengan pendekatan sektoral sudah banyak gagal (Lubchenko 2010; Ehler dan
Douvere 2010). Pengelolaan perairan pesisir (P3) berbasis zonasi sangat memungkinkan untuk mengakomodasi banyak sektor dalam suatu kawasan (zona), dengan kriteria-kriteria yang disepakati secara bersama-sama (Ehler \& Douvere 2010; Shucksmith \& Kelly 2014). Dengan mekanisme zonasi, P3 berbasis ekosistem dapat diakomodasi dan kegiatan ekonomi yang berkelanjutan diharapkan dapat terwujud. 
Kawasan perairan pesisir pulau Wangi-wangi di kabupaten Wakatobi, provinsi Sulawesi Tenggara juga telah mengalami tekanan akibat aktifitas manusia (anthropogenic activities) (Chandra 2012; Sopari et al. 2014). Pulau Wangi-wangi (Gambar 1) merupakan salah satu dari empat pulau utama di kabupaten Wakatobi, yaitu Kaledupa Tomia, Binongko yang berada dalam kawasan Taman Nasional Laut (TNL) Wakatobi, yang memiliki luas sekitar 1,39 juta hektar. Penetapan TNL Wakatobi didasarkan pada Keputusan Menteri Kehutanan No.7651/ Kpts-II/ 2002, tanggal 19 Agustus 2002. Pada tanggal 18 Desember 2003, Wakatobi resmi ditetapkan sebagai salah satu kabupaten pemekaran di Sulawesi Tenggara, yang terbentuk berdasarkan Undang - Undang Nomor 29 tahun 2003, tentang pembentukan Kabupaten Bombana, Kabupaten Wakatobi dan Kabupaten Kolaka Utara. Dengan menjadi suatu pemerintahan kabupaten, maka aktifitas ekonomi semakin meningkat pada TNL ini, khususnya pulau Wangi-wangi, sebagai ibukota kabupaten. Pemda Wakatobi pada tahun 2013, telah berencana untuk membangun PLTU dengan bahan baku batubara di pulau Wangi-Wangi. Namun demikian, karena terjadi perubahan rencana dari PT. PLN, maka yang akan dibangun adalah PLTG.

Peristiwa eutrofikasi (eutrophication) akan menurunkan pertumbuhan terumbu karang dan menyebabkan terjadinya gejala hipoksia (hypoxia) sebagai parameter awal (Gray et al. 2002; Sidabutar 2012; Moberg \& Folke 1999). Dalam jangka panjang, jika kondisi eutrofikasi berlangsung lama, maka akan terjadi kematian terumbu karang (Rabalais 2010). Contoh paling umum adalah tidak adanya terumbu karang pada daerah sekitar muara sungai. Terumbu karang umumnya berada pada daerah yang rendah limpahan sedimentasi dari daratan.

Terumbu karang memerlukan kestabilan dari suhu, $\mathrm{pH}$, siklus cahaya, aliran air, salinitas dan komposisi kimia untuk bertumbuh (Rose 2009). Sebagai produsen primer (zooxantellae dalam terumbu karang), keberadaan terumbu karang penting sekali dalam ekosistem perairan laut. Keberadaan terumbu karang akan menjaga keberlangsungan aktifitas perikanan dan terkait langsung dengan aktifitas ekonomi. Menjaga ekosistem terumbu karang sama berartinya dengan menjaga aktifitas perikanan dan ekonomi.

Kondisi terumbu karang di Wangi-wangi berdasarkan data pengukuran dasar (baseline) oleh LIPI dalam proyek COREMAP II, tahun 2006, yang dalam kondisi baik, antara lebih dari $25 \%$ sampai dengan lebih dari $75 \%$ berada di bagian utara dan timur pulau (Gambar 2). Pada tahun 2011, berdasarkan hasil kajian proyek COREMAP III menunjukkan tidak terjadinya perubahan kondisi terumbu karang di Wakatobi (World Bank 2012). Hal ini menunjukkan beban lingkungan dari aktifitas manusia relatif rendah. Sedangkan daerah lain di Indonesia menunjukkan tren bertumbuh (Tabel 1, Lampiran).
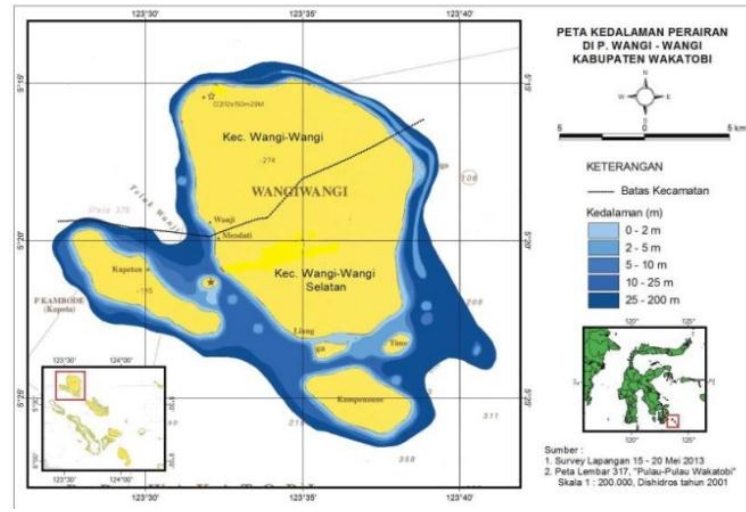

Gambar 1. Lokasi Pulau Wangi-wangi di TNL Wakatobi (Yulius et al. 2015).

Figure 1. The Wangi-wangi island in Wakatobi (Yulius et al., 2015)

Alcala (1988) menyebutkan nilai hasil perikanan yang terkait dengan terumbu karang di Filipina sekitar 11- 24 ton per kilometer persegi per tahun. Jika luas kawasan terumbu karang di pulau Wangi-Wangi sekitar $130 \mathrm{~km}^{2}$, maka potensi hasil perikanan terkait terumbu karang sekitar 1.430 3.120 ton per tahun. Dengan demikian, konservasi ekosistem terumbu karang adalah sangat penting. 


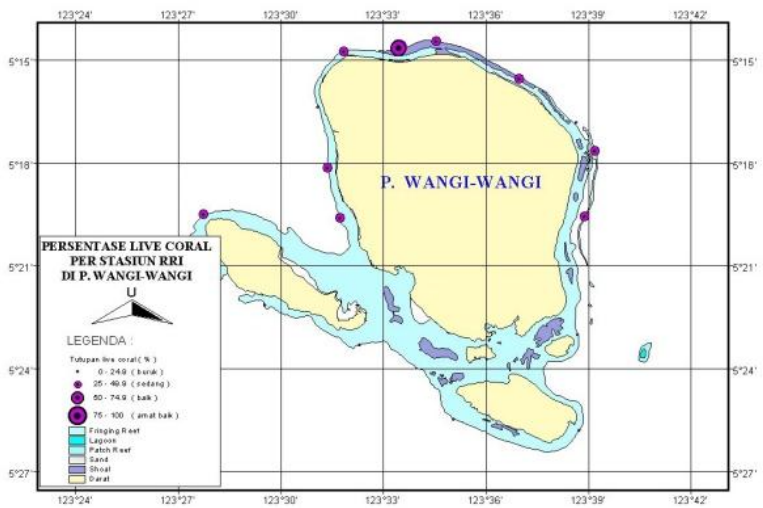

Gambar 2. Prosentasi (\%) karang hidup di sekitar pulau Wangi-wangi, Wakatobi. Paling tinggi lebih dari $75 \%$ pada bagian utara dan timur (sumber: coremap.or.id).

Figure 2. The percentage (\%) of live coral reefs around Wangi-wangi island, Wakatobi. Highes rate more than $75 \%$ is located on northern and eastern part (source: coremap.or.id)

Berdasarkan buku Pedoman teknis Rencana Zonasi wilayah pesisir dan pulau-pulau kecil (RZWP3K), dalam rangka pengumpulan data dan informasi untuk perencanaan zonasi perairan pesisir kabupaten, digunakan beberapa teknik untuk melakukan survei di lapangan yang antara lain (Direktorat Tata Ruang Laut 2013): observasi, pengambilan sampel, pengukuran, wawancara, penyebaran kuesioner dan focus group discussion (FGD). Pengukuran dan observasi perairan pesisir untuk perencanaan zonasi perairan kabupaten/kota selama ini belum menggunakan data parameter biofisik waktu serial. Umumnya, karena keterbatasan waktu dan anggaran, hanya dilakukan pengumpulan data parameter biofisik selama 1-2 minggu, bahkan berdasarkan hasil diskusi yang kadang hanya dilaksanakan dalam tiga (3) hari. Proses RZWP3K bukan merupakan riset ilmiah namun merupakan proses publik (Ehler \& Douvere 2010). Namun demikian, data dan informasi yang dipergunakan memanfaatkan hasil riset, baik data temporal, serial dan informasi spasial.

Tujuan penelitian ini adalah menganalisis pemanfaatan data waktu serial pemonitoran perairan pesisir dalam rangka penyusunan rencana zonasi untuk P3. Penelitian ini memiliki faktor inovasi yang penting, karena berusaha untuk mengkaji hal baru - berupa pemakaian data waktu serial - yang diaplikasikan pada rencana zonasi perairan pesisir. Juga melakukan pengujian inovasi alat yang dipergunakan.

\section{BAHAN DAN METODE}

\section{Bahan}

Dalam kegiatan ini, dipergunakan peralatanperalatan dan teknologi pemantauan kualitas perairan secara waktu serial (berseri), yang sudah dipatenkan, diujikan dan dipakai di banyak tempat, yaitu buoy PLUTO (Chandra et al. 2014; Krismono dan Astuti 2016). Sensor yang terpasang adalah suhu, salinitas, $\mathrm{pH}$ dan kandungan oksigen (DO), menggunakan sensor Tripod dari Ponsel (Perancis), pada kedalaman 5m dan $25 \mathrm{~m}$. Lokasi penempatan pada $5^{0} 15^{\prime} 155^{\prime}$, LS dan $123^{\circ} 32$ ' $528^{\prime \prime}$ BT. Rangkaian sensor pada tiap kedalaman adalah: $5 \mathrm{~m}$ (DO, Suhu), pada kedalaman $25 \mathrm{~m}$ (DO, Suhu, Salinitas, dan $\mathrm{pH}$ ), merek Ponsel. Untuk pengukuran sebaran parameter suhu dan DO dipergunakan sensor ProDSS dari YSI (USA).

\section{Pengumpulan Data}

Pengumpulan data dilakukan dalam beberapa tahapan. Tahapan pertama adalah melakukan perekayasaan alat buoy PLUTO dua kedalaman pemonitoran $(5 \mathrm{~m}$ dan $25 \mathrm{~m})$. Selanjutnya, dilakukan kalibrasi alat sensor dengan Sensor Tripod dari Ponsel yang ada di buoy PLUTO dengan Pro-DSS dari YSI (USA), agar diperoleh kesamaan data waktu serial dengan data sebaran horizontal. Kemudian, dilakukan instalasi peralatan buoy PLUTO pada bulan Agustus 2015. Setelah instalasi alat untuk pengukuran data waktu serial, dilanjutkan pengukuran data sebaran parameter perairan menggunakan Pro-DSS bulan Juni 2016. Data sebaran parameter biofisik dilakukan pada kedalaman permukaaan $(1 \mathrm{~m})$ dan 30 meter.

\section{Perekayasaan Alat}

Tahap pertama dalam perekayasaan adalah penyusunan disain alat, yang didasarkan pada kriteria-kriteria teknis yang ditetapkan dan juga kondisi lapang (Chandra, 2012; Wagner et al., 2006). Setelah dilakukan desain, maka selanjutnya dilakukan perhitungan hidrostatik dengan menggunakan perangkat lunak Hydromax Pro 
versi 11.12. Berdasarkan kriteria stabilitas statis, buoy PLUTO dua kedalaman sudah memenuhi kriteria yang disyaratkan (Gambar 3). Selanjutnya dilakukan survey lokasi untuk penempatan alat buoy tersebut. Analisis mooring dilakukan dengan menggunakan software CFD (Computerized Fluid Dynamics), yang menghasilkan jenis tali PP (polypropylene) dengan diameter $10 \mathrm{~mm}$ sepanjang $30 \mathrm{~m}$, rantai $10 \mathrm{~m}$, tali sensor terdalam yang tercelup di air sebesar $25 \mathrm{~m}$. Kalibrasi alat untuk dua jenis sensor berbeda merek dilakukan mengunakan dengan cara langsung, yaitu memakai bahan air yang sama dan dilakukan pengukuran ditempat yang sama, menggunakan sensor Tripod (Ponsel) dan Pro-DSS (YSI). Pengukuran suhu, $\mathrm{pH}$, DO dan salinitas relatif sama. Suhu air 27,32 (Tripod) dan 27,33 (ProDSS); pH 7,92 dan 7,91; DO 7,17 dan 7,18; salinitas 0.01 dan $0.01 \mathrm{ppm}$. Pembelian dua alat ini dilakukan tahun 2015 secara bersama-sama. Namun demikian, pemakaian alat Pro-DSS baru dilakukan tahun 2016 untuk data sebaran spasial (spatial distribution).
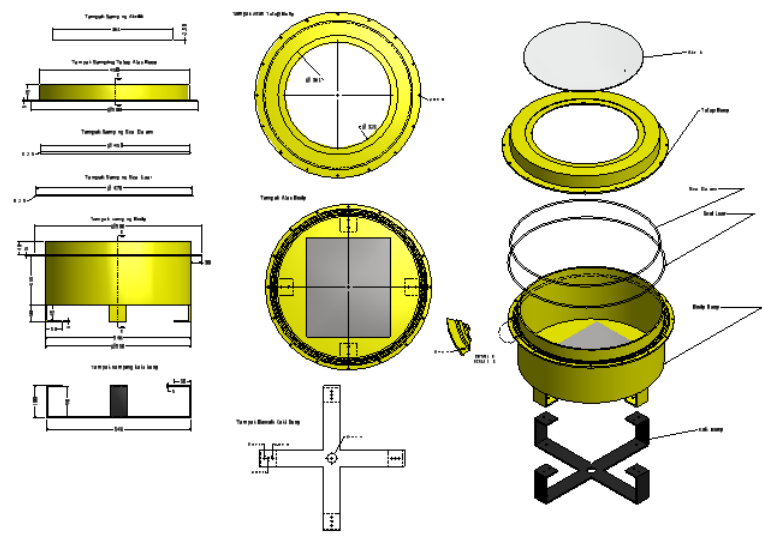

Gambar 3. Disain buoy PLUTO dua kedalaman pemonitoran.

Figure 3. The PLUTO buoy design for two (2) depth monitoring.

\section{Analisis Data}

Metode analisis data waktu serial dilakukan dengan menggunakan dua parameter saja (suhu dan DO). Pengolahan data perairan waktu serial menggunakan perangkat lunak Microsoft Excel. Pembahasan dilakukan setelah hasil olahan data diperoleh. Rekomendasi zonasi untuk P3 berdasarkan data biofisik waktu serial, berdasarkan buku Petunjuk Teknis penyusunan RZWP3K (Direktorat Tata Ruang Laut 2013). Untuk data sebaran parameter biofisik, data diolah menggunakan perangkat lunak GIS (Geographical Information System), dengan metode inverse distance weighting (IDW).

\section{HASIL DAN PEMBAHASAN}

Data waktu serial suhu pada kedalaman $5 \mathrm{~m}$ dan $25 \mathrm{~m}$ dapat dilihat pada Gambar 4. Perbedaan suhu antara dua kedalaman tidak begitu besar atau berarti, selama 5 bulan (September 2015 - Januari 2016). Pada kedalaman 0-25 meter, suhu perairan relatif stabil karena masih dalam zona lapisan tercampur (mixed layer zone). Zona lapisan tercampur ini dipengaruhi oleh angin, ombak dan arus sepanjang pantai (longshore current) (Stewart 2008). Selain itu, lokasi penempatan buoy PLUTO masih di perairan pesisir dan bentuk topografi dasar perairan berbentuk laguna, sehingga dinamika perairannya relatif stabil (Davis \& Fitzgerald 2004).

Perairan pesisir adalah laut yang berbatasan dengan daratan meliputi perairan sejauh 12 mil laut $(21,6 \mathrm{~km})$ diukur dari garis pantai, perairan yang menghubungkan pantai dan pulau-pulau, estuari, teluk, perairan dangkal, rawa payau, dan laguna (UU No. 1, 2014). 


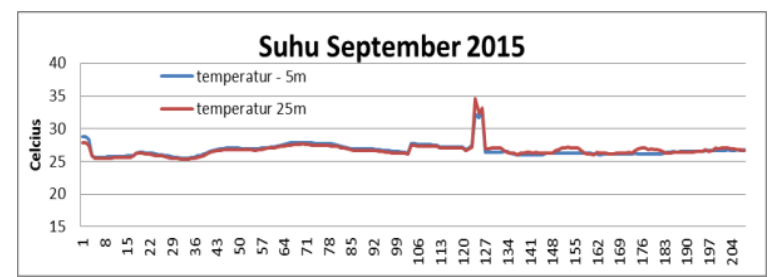

(a)

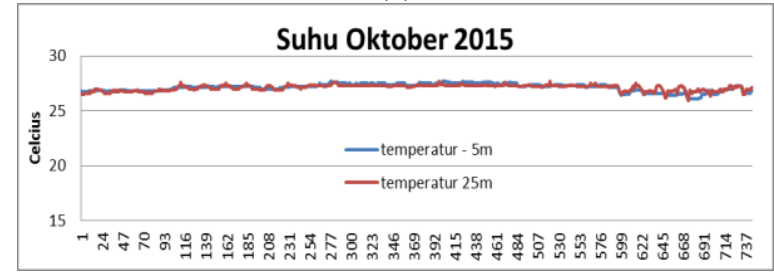

(b)

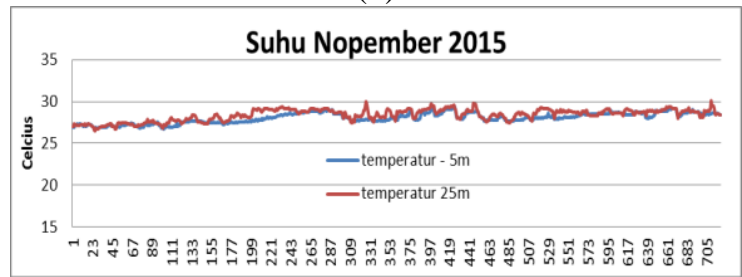

(c)

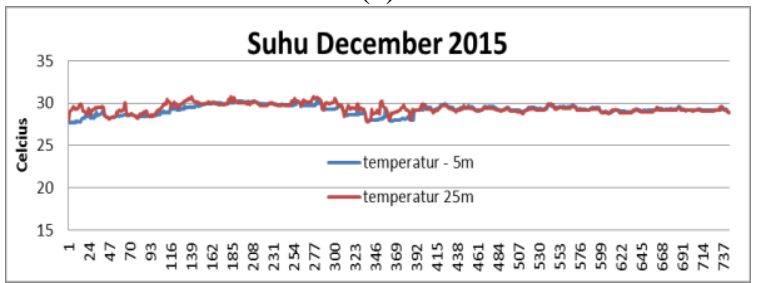

(d)

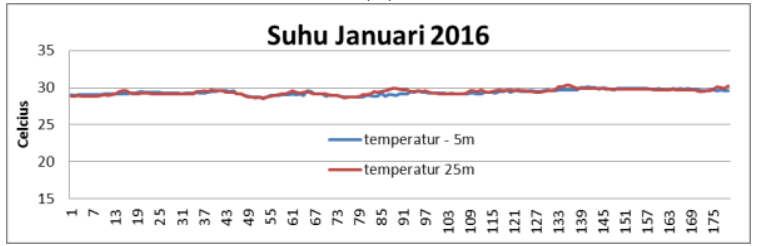

(e)

Gambar 4. Data serial waktu suhu di kedalaman $5 \mathrm{~m}$ dan 25m dari buoy PLUTO, bulan September 2015 (a), Oktober 2015 (b), Nopember 2015 (c), Desember 2015 (d) dan Januari 2016 (e).

Figure 4. The time series data of temperature at depth $5 m$ and $25 m$ by using PLUTO buoy, on September 2015 (a), October 2015 (b), November2015 (c),

December 2015 (d) dan January 2016 (e).

Untuk data waktu serial kandungan oksigen (DO) pada kedalaman $5 \mathrm{~m}$ dan $25 \mathrm{~m}$ dapat dilihat pada Gambar 5. Pengaruh perbedaan kedalaman terhadap nilai kandungan oksigen ternyata juga terjadi di perairan pesisir pulau Wangi-wangi. Kondisi serupa juga pernah terjadi di Amerika Serikat (Rabalais et al. 2009; Howarth et al. 2000;
Kite-Powel 2009), Jakarta (Sidabutar 2012) dan Pekalongan (Chandra et al. 2014).

Perairan pesisir yang tidak dikelola dengan baik, sehingga input nitrogen (dalam bentuk nitrat atau $\mathrm{NO}_{3}$ ) sangat tinggi dari daratan, bisa menjadi zona kematian (death zone) bagi biota yang hidup 
didalamnya (Rabalais et al. 2009; Howarth et al. 2000; Sidabutar 2012; Chandra et al. 2014). Zona kematian ditunjukkan dengan nilai kandungan oksigen sangat rendah (anoksik: 0-2 mg/L) pada perairan tersebut. Kawasan kolam pelabuhan umumnya menjadi zona kematian karena tidak adanya pengelolaan limbah (kapal maupun dari daratan) (Chandra et al. 2014; Kepmen LH 51 2004).

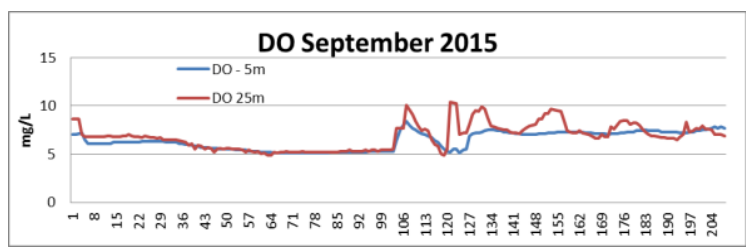

(a)

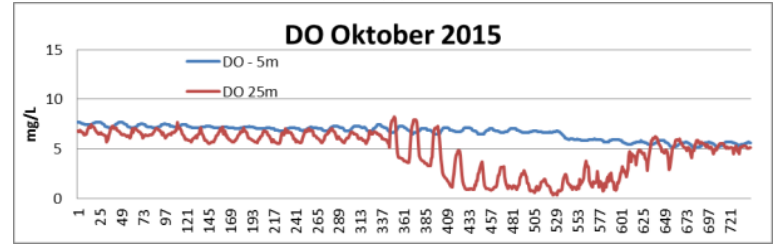

(b)

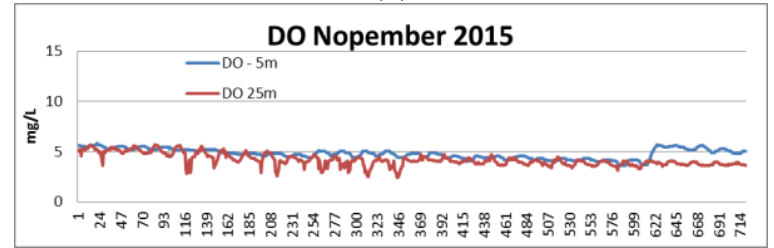

(c)

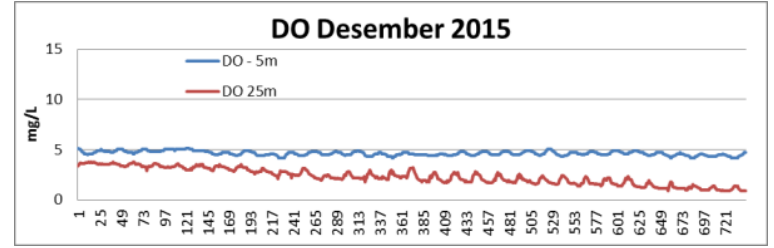

(d)

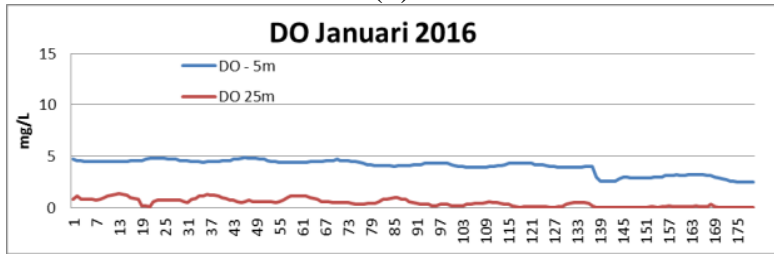

(e)

Gambar 5. Data serial waktu DO di kedalaman 5m dan 25m dari buoy PLUTO, bulan September (a), Oktober 2015 (b), Nopember 2015 (c), Desember 2015 (d) dan Januari 2016 (e).

Figure 5. The time series data of dissolved oxygen at depth $5 \mathrm{~m}$ and $25 \mathrm{~m}$ by using PLUTO buoy, on

September 2015 (a), October $2015(b)$, November 2015

(c), December 2015 (d) and January $2016(e)$.

Kondisi hipoksia (2-4 mg/L) dan anoksia terjadi pada kedalaman $25 \mathrm{~m}$ karena perairan mulai dipengaruhi angin barat (west monsoon) pada bulan Desember-Februari (Gordon 2005; Wyrtki 2005). Meningkatnya curah hujan menyebabkan dasar perairan menjadi keruh dengan sedimen dan 
mengakibatkan turunnya kandungan oksigen. Sedangkan pada musim angin timur (east monsoon), pada bulan Juni-Agustus, umumnya tidak terjadi hujan yang mengakibatkan kandungan oksigen relatif sama (Gambar 4 (a)). Berdasarkan data musim dan data pengukuran kuantitatif ini, pada musim angin timur, daerah perairan pesisir Waha dapat dijadikan zona wisata. Sedangkan pada musim angin barat tidak cocok.

Pengukuran sebaran parameter perairan pada 23 Juni 2016, dilakukan dengan menggunakan alat Pro-DSS merek dari YSI. Parameter yang diukur yaitu suhu (dalam satuan ${ }^{0} \mathrm{C}$ ) dan DO (dalam satuan $\mathrm{mg} / \mathrm{L}$ ). Penyajian hasil pengukuran memakai metode IDW (Ruberg et al. 2008; Jiang et al. 2014).

Sebaran suhu permukaan (1m) pada Gambar 6(a) berbeda dengan suhu pada kedalaman $30 \mathrm{~m}$ pada gambar 6(b). Pada kedalaman $1 \mathrm{~m}$, suhu tertinggi berada pada stasiun (lokasi) 3 dan lokasi 9 sebesar $29,2^{\circ} \mathrm{C}$. Suhu pada lokasi 1,7 dan 12 merupakan yang terendah sebesar $28,6^{\circ} \mathrm{C}$. Terdapat perbedaan sekitar $0,6{ }^{\circ} \mathrm{C}$. Aktifitas manusia dan ekonomi dikawasan pelabuhan terbukti memberikan dampak terhadap tingginya suhu perairan pesisir Wangi-wangi. Lokasi 3 dan 9 memiliki topografi dasar yang dangkal $(0-5 \mathrm{~m})$, sehingga pengaruh daratan masih kuat dan pengaruh sirkulasi air yang relatif rendah diduga juga merupakan faktor tingginya suhu daerah tersebut dibandingkan titik sampel yang di laut dalam. Chandra et al. (2014) Selain itu juga telah melakukan pengukuran secara kuantitatif di pelabuhan perikanan Nusantara Pekalongan, dan mendapatkan hasil serupa (suhu kolam pelabuhan lebih tinggi daripada perairan sekitar).

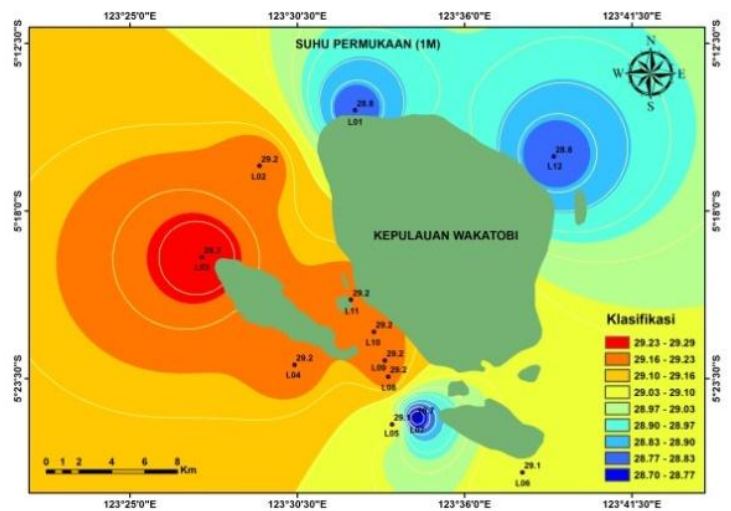

(a)

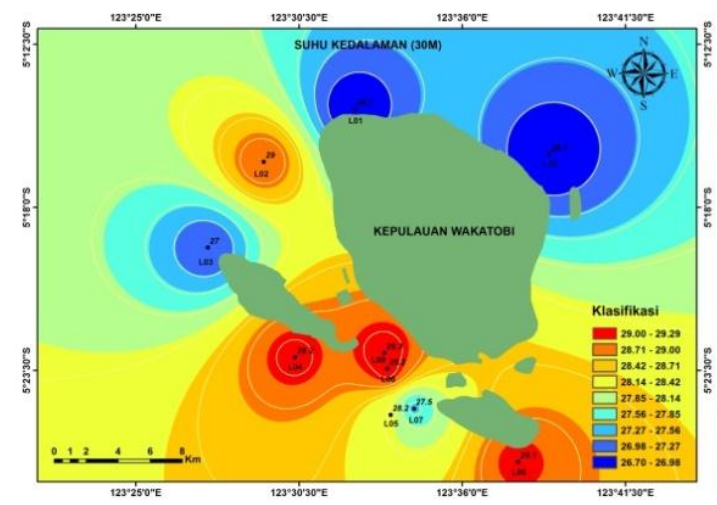

(b)

Gambar 6. Sebaran parameter temperature pada kedalaman $1 \mathrm{~m}$ (a), menggunakan metode Inverse Distance Weighted (IDW) dari perangkat lunak ArcGIS. Sebaran parameter suhu pada kedalaman 30m (b).

Figure 6. The temperature parameter distribution at $1 m$ depth (a), by using IDW method in ArcGIS software. Temperature parameter at $30 \mathrm{~m}$ depth (b).

Perbedaan nilai kandungan oksigen (DO) juga terlihat pada kedalaman $1 \mathrm{~m}$ pada Gambar 7(a) dan $30 \mathrm{~m}$ pada Gambar 7(b). Nilai tertinggi sebesar $5,88 \mathrm{mg} / \mathrm{L}$ dan terendah sebesar $4,62 \mathrm{mg} / \mathrm{L}$ pada kedalaman $1 \mathrm{~m}$. Pada gambar itu, nilai kandungan oksigen (DO) di pelabuhan juga lebih rendah dibandingkan dengan perairan lainnya (warna biru), walau nilainya masih diatas $4 \mathrm{mg} / \mathrm{L}$. Berdasarkan Kepmen LH 51, 2004 ( Tabel 2, ), maka perairan pesisir sekeliling Wangi-wangi masih bagus untuk baku mutu Wisata Bahari dan Biota. Meskipun daerah tertentu - seperti pelabuhan, dan selat dari arah barat laut pelabuhan - sudah masuk kategori baku mutu 
pelabuhan.

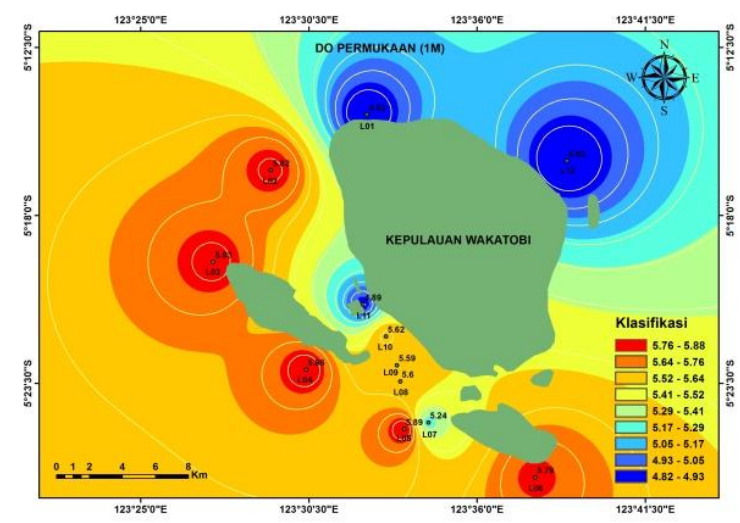

(a)

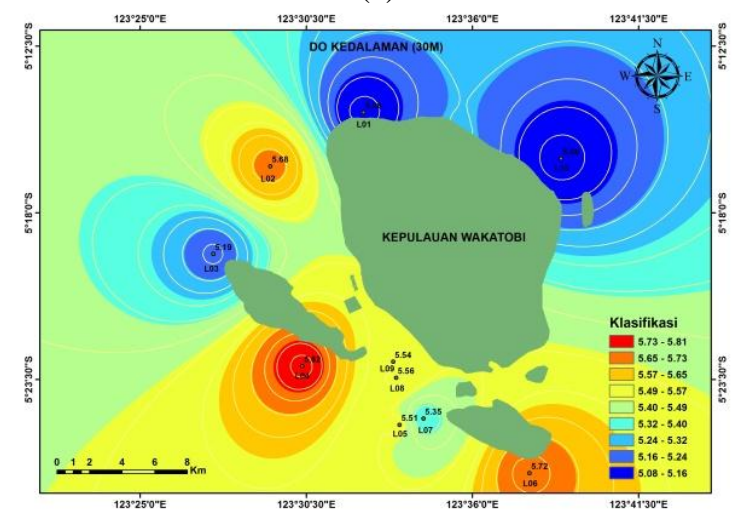

(b)

Gambar 7. Sebaran parameter kandungan oksigen (mg/L) pada kedalaman $1 \mathrm{~m}$ (a). Sebaran parameter kandungan oksigen pada kedalaman 30m (b).

Figure 7. The dissolved oxygen parameter $\left(\mathrm{mg} \mathrm{L}^{-1}\right)$ distribution at $1 \mathrm{~m}$ depth (a), by using IDW method in ArcGIS software. The dissolved oxygen parameter at $30 \mathrm{~m}$ depth $(b)$.

Borja et al. (2016) memberikan kriteria pengumpulan data yang baik, yaitu transparan, dapat dilakukan pengulangan (repeatable) baik alat ukur maupun metoda pengukuran, dan mudah dikomunikasikan pada semua pihak (saintis, pengambil kebijakan, menejer, pemerintahan, dan masyarakat). Parameter suhu dan DO adalah parameter yang transparan, dapat diulang dan mudah dikomunikasikan pada semua pihak. Chandra (2012) telah melakukan pengukuran parameter suhu, salinitas, dan DO di daerah Liya tahun 2010-2011, dan terekam dinamika suhu perairan akibat pengaruh musim angin timur dan barat. Pada musim angin barat, penyakit ice-ice pada rumput laut tipe euchema cotonii, meningkat karena suhu dan salinitas perairan turun.
Penurunan kualitas lingkungan menyebabkan kerugian bagi pembudidaya rumput laut.

Zonasi adalah suatu bentuk rekayasa teknik pemanfaatan ruang, melalui penetapan batas-batas fungsional sesuai dengan potensi sumber daya alam, daya dukung dan proses-proses ekologis yang berlangsung, sebagai satu kesatuan dalam ekosistem pesisir (Direktorat Tata Ruang, 2013). Penetapan zonasi dengan menggunakan data waktu serial (time series), di pulau Wangi-wangi wajib mempertimbangkan ketiga aspek tersebut. Sudah menjadi pengetahuan umum, bahwa sumber daya utama perairan pesisir pulau Wangiwangi adalah terumbu karang (coral reefs). Terumbu karang ini hidup mulai dari permukaan perairan sampai dengan kedalaman 30-40m, yaitu cahaya matahari masih dapat berpenetrasi. Daya dukung perairan untuk dapat mempertahankan keberadaan terumbu karang adalah suhu, $\mathrm{pH}$, kekeruhan dan salinitas yang stabil (Kepmen LH 51 2014; Kite-Powell 2009, Rose 2009). Mempertahankan kualitas perairan akan menjamin keberlangsungan ekosistem terumbu karang, yang juga akan menjamin keberlanjutan aktifitas perikanan karang (demersal) yang bernilai 11-24 ton per kilometer persegi per tahun (Alcala 1988).

Berdasarkan hasil survey data dasar tahun 2006, yaitu titik-titik kondisi karang yang masih baik ada di bagian utara dan timur pulau (coremap.or.id), dikarenakan kondisi air pada daerah tersebut masih baik dan sesuai dengan Permen LH no.51, 2004. Korelasi beban antropogenik terhadap kondisi terumbu karang berbanding terbalik (Rabalais et al. 2009; KitePowel 2009; Sidabutar 2012; Chandra et al. 2014). Jika tekanan antropogenik semakin tinggi, kondisi tutupan terumbu karang semakin rendah. Jadi, kondisi tutupan terumbu karang yang baik pada tahun 2006 di bagian utara dan timur, jika dikaitkan dengan sebaran parameter air di tahun 2016, masih relevan. Hanya saja tidak ada data waktu serial yang bisa menunjukkan apakah terjadi perubahan besar dalam rentang waktu 10 tahun. Pada saat dilakukannya survey oleh COREMAP (2006) tentu sangat berbeda dengan tahun 2016. Jumlah penduduk dan aktifitas ekonomi sudah berbeda jauh, apalagi dengan akan dibangunnya PLTG di pulau tersebut, yang 
direncanakan selesai pada akhir 2016.

Seperti disepakati bersama, bahwa proses zonasi dan penyusunannya merupakan proses publik, maka sosialisasi ancaman habitat/ekosistem dan kesepakatan dari berbagai pihak untuk berupaya memperbaiki dan memeliharanya perlu diusahakan. Proses dialog, negosiasi, serta konsultasi, dan yang terpenting terkait dengan informasi dan data perlu dibuka ke publik, agar proses untuk mencapai rencana zonasi dan upaya perlindungan ekosistem melalui Perda atau hukum adat dapat efektif (Sopari et al. 2014). Untuk pulau Wangi-wangi, berdasarkan data pengukuran secara temporal dan spasial yg telah dilakukan, dapat ditentukan prinsip zonasinya untuk wilayah pesisir utara dan timur harus diupayakan menjadi daerah konservasi. Wilayah barat dan selatan perairan pulau daerah dipergunakan untuk zona aktifitas ekonomi. Data, informasi, dan indikator yang sudah disajikan dapat menjadi contoh baru untuk aplikasi perencanaan zonasi WP3K berdasarkan waktu serial.

\section{KESIMPULAN DAN SARAN}

Data waktu serial untuk perencanaan zonasi perairan pesisir sangat penting dan berdasarkan hasil analisis memberikan nilai yang berbeda saat musim angin timur dan angin barat. Hal ini menunjukkan dinamika perairan dapat terbaca dengan adanya data waktu serial. Data in-situ waktu serial memperlihatkan perbedaan parameter biofisik (suhu dan DO) pada musim angin timur dan barat. Juga secara spasial, terdapat perbedaan pada kedalaman $1 \mathrm{~m}$ dan $30 \mathrm{~m}$. Hasil penelitian juga menunjukkan bergunanya alat yang dirancang khusus (inovasi) untuk pengukuran paramater perairan secara waktu serial.

\section{DAFTAR PUSTAKA}

Alcala, A.C. 1988. Effects of marine reserves on coral fish abundances and yields of Philippine coral reefs. Ambio 17(3): 194199.)

Arnold L. Gordon. 2005. Oceanography of the Indonesian Seas and Their Throughflow. Oceanography, Journal of Oceanography Society. Vol. 18, No. 4, Dec. 2005.
Borja A, Eliott M, Andersen JH, Berg T, Carstensen J, Halpern BS, Heiskanen AS, Korpinen S, Lowndes JSS, Martin G and Rodrigues-Ezpeleta N. 2016. Overview of Integrative Assesment of Marine Systems: The Ecosystem Approach in Practice. Front. Mar. Sci. 3:20. doi: 10.3389/fmars.2016.00020. Frontiers in Marine Science, Review, Published: 01 March 2016.

Chandra H. 2012. Perekayasaan Buoy Pluto Untuk Memantau Kualitas Perairan Budidaya Rumput Laut Di Kabupaten Wakatobi, Sulawesi Tenggara. Jurnal Kelautan Nasional Volume 7, No.3, Desember 2012.

Chandra H, Sianturi DA, Firdaus Y. 2014. Uji Performansi Buoy Pluto Untuk Peringatan Dini Pencemaran Perairan. Jurnal Kelautan Nasional, Vol. 9, No. 3, Desember 2014. ISSN: 1907 - 767X. Akreditasi LIPI no. 486/AU2/P2MI LIPI/8/2012

Davis, RA Jr dan Fitzgerald, DM. 2004. Beaches and Coasts. Blackwell Science Ltd, UK. ISBN: 978-0-632-04308-8.

Direktorat Tata Ruang Laut Pesisir dan Pulaupulau Kecil. 2013. Pedoman Teknis Penyusunan Rencana Zonasi Wilayah Pesisir dan Pulau-Pulau Kecil (RZWP3K) Kabupaten/Kota. Direktorat Tata Ruang Laut Pesisir dan Pulau-pulau Kecil, Dirjen KP3K, Kementerian Kelautan dan Perikanan. 2013.

Ehler C and Fanny D. 2010. Marine Spatial Planning: a step-by-step approach toward ecosystem-based management. Intergovernmental Oceanographic Commission and Man and the Biosphere Programme. IOC Manual and Guides No. 53, ICAM Dossier No. 6. Paris: UNESCO. 2009 (English).

Gray, J.S., Wu R.S.S., Or Y.Y. (2002). Effects of hypoxia and organic enrichment on the coastal marine environment. Mar. Ecol. Prog. Ser. 238,249-79

Howarth R, Anderson D, Cloem J, Elfring C, Hopkinson C, Lapointe B, Malone T, Marcus N, McGlathery K, Sharpley A, Walker D. 2000. Nutrient Pollution of 
Coastal Rivers, Bays, and Seas. Issues in Ecology, no. 7, Fall 2000. Ecological Society of America, $1707 \mathrm{H}$ street, suite 400, Washington DC.

Jane Lubchenco. 2010. Changing Course. A Proposed Framework for Coastal and Marine Spatial Planning in the United States. National Wetlands Newsletter, Vol. 32, No.4, July-August 2010. Web site: wwwl.eli.org

Jiang, Yu-Jiao; Wei He, Wen-Xiu Liu, Ning Qin, Hui-Ling Ouyang, Qing-Mei Wang,Xiang-Zhen Kong, Qi-Shuang He, Chen Yang, Bin Yang, Fu-Liu Xu. 2014. The seasonal and spatial variations of phytoplankton community andtheir correlation with environmental factors in a large eutrophic Chinese lake (Lake Chaohu). Ecological Indicators Journal, 40(2014) 58-67. Elsevier Ltd.

Kite-Powell HL. 2009. A global Perspective on the economics of ocean acidification. Current, The Journal of Marine Education, vol. 25, no. 1, 2009. Pp 25-29. NMEA, USA.

Krismono dan Astuti, LP. 2016. Analisis Lokasi Pemasangan Buoy PLUTO di Perairan Waduk dan Danau. Aplikasi Teknologi Pemantauan Kualitas Perairan - Editor Handy Chandra \& Hari Eko Irianto. Penerbit Universitas Indonesia, ISBN: 978-979-456-653-4. 2016.

Keputusan Menteri Kehutanan No.7651/ Kpts-II/ 2002, tanggal 19 Agustus 2002. Tentang Taman Nasional Laut Wakatobi.

Keputusan Menteri Negara Lingkungan Hidup, Nomor: 51 Tahun 2004. Tentang Baku Mutu Air Laut.

Mitsch, WJ and Jorgensen SE. 2004. Ecological Engineering and Ecosystem Restoration. John Wiley \$ Sons, New Jersey, USA.

Moberg, F. and Folke, C. 1999. Ecological goods and services of coral reef ecosystems. Journal of Ecological Economics 29 (1999) 215 - 233. Elsevier Science BV.

Peraturan Pemerintah Republik Indonesia, Nomor 21, Tahun 2010, Tentang Perlindungan Lingkungan Maritim.

Pusat Pengkajian dan Perekayasaan Teknologi Kelautan dan Perikanan (P3TKP), Badan Penelitian dan Pengembangan Kelautan dan Perikanan, Kementerian Kelautan dan Perikanan. 2015. Rekayasa Alat Pemantau Kualitas Perairan Dengan Dua Lapis Kedalaman Di Kawasan Konservasi. Laporan Akhir Penelitian.

Rabalais NN, Turner RE, Diaz RJ, Justic D. 2009. Global change and eutrophication of coastal waters. ICES Journal of Marine Science, 66: 1528 - 1537.

Ruberg SA, Edwin Guasp, Nathan Hawley, Ronald W. Muzzi, Stephen B. Brandt, Henry A. Vanderploeg, John C. Lane, Terry Miller, Stephen A. Constant. 2008. Societal Benefits of the Real-Time Coastal Observation Network (ReCON): Implications for Municipal Drinking Water Quality. Marine Technology Society Journal, Fall 2008, Vol 42, Number 3.

Rose, Alex. 2009. Coral Reef Ecology. www.coralscience.org

Sopari H, Oka NP, Salman D. 2014. Model kolaborasi perencanaan antara Balai Taman Nasional Wakatobi dan pemerintah kabupaten Wakatobi dalam pengelolaan sumberdaya alam hayati secara lestari. J. Sains dan Teknologi, Agustus 2014, Vol. 14 no. 2: 189-198. ISSN: 1411-4674.

Sidabutar, Tumpak. 2012. Kajian Eutrofikasi Dan "Harmful Algal Blooms" Di Perairan Teluk Jakarta. Prosiding Seminar Nasional Perikanan Indonesia 13-14 November 2012, STP, Jakarta. Hal 481-490.

Shucksmith RJ and Kelly C. 2014. Data Collection and mapping - Principles, processes and application in marine spatial planning. Marine Policy, 50 (2014) 27-33. Elsevier, Ltd.

Stewart, Robert H. 2008. Introduction To Physical Oceanography. Department of Oceanography Texas A \& M University, Copyright 2008.

Undang-undang, Nomor 29, tahun 2003. Tentang pembentukan Kabupaten Bombana, Kabupaten Wakatobi dan Kabupaten Kolaka Utara. 18 Desember 2003.

Undang-undang, Nomor 1, tahun 2014. Tentang Perubahan atas UU No. 27 tahun 2007, 
tentang Pengelolaan Wilayah Pesisir dan Pulau-Pulau Kecil. 15 Januari 2015.

Wagner RJ, Mattraw HC, Ritz GF \& Smith BA. 2006. Guidelines and standard procedures for continuous water-quality monitors: Site selection, field operation, calibration, record computation, and reporting. US Department of the Interior, US Geological Survey Techniques and Methods 1-D3, 51 p. +8 attachments.

World Bank. 2012. Report No: ICR2245. Implementation Completion And Results Report (Tf-26799, Ibrd-47400, Ida-39100, Tf-53350). The Coral Reef Rehabilitation
And Management Project (Phase Ii) (COREMAP II). June 25, 2012.

Wyrtki K. 2005. Discovering the Indonesian Throughflow. Oceanography Vol. 18, No. 4, Dec. 2005.

Yulius, Salim HL, Ramdhan M. 2015. Spatial Pattern of Bathymetry in Wangi-Wangi Island and its Surrounding Based on GEBCO Data and Nautical Map. Forum Geografi, Vol 29 (2) December 2015: 143 151. ISSN: 0852-0682, E-ISSN: 24603945 . 


\section{Lampiran Tabel.}

Tabel 1. Kesehatan terumbu karang (berdasarkan tutupan karang hidup) dari plot permanen LIPI (Document of World Bank, 2012)

Table 1. The Coral Reef health (based on coral coverage) from LIPI's permanet plotting (Document of World Bank, 2012)

\begin{tabular}{lcccccc}
\hline No. District & 2006 & 2007 & 2009 & 2010 & 2011 & \% Increase \\
\hline 1. Pangkep (Tanpa Kalmas) & 32 & 30 & 38 & 41 & 38 & $\mathbf{+ 1 9 \%}$ \\
2. Selayar & 32 & 34 & 36 & 43 & 45 & $\mathbf{+ 4 0} \%$ \\
3. Buton & 34 & 36 & 38 & 30 & 41 & $\mathbf{+ 1 8 \%}$ \\
4. Wakatobi & 46 & 47 & 47 & 42 & 46 & $\mathbf{0 \%}$ \\
5. Raja Ampat (tanpa Batang Pele) & 22 & 20 & 27 & 29 & 30 & $\mathbf{+ 3 3 \%}$ \\
6. Biak & 23 & 28 & 26 & 20 & 18 & $\mathbf{- 2 3 \%}$ \\
7 Sikka & 18 & 17 & 13 & 21 & 25 & $\mathbf{+ 4 2 \%}$ \\
& $\mathbf{3 0}$ & $\mathbf{3 0}$ & $\mathbf{3 2}$ & $\mathbf{3 2}$ & $\mathbf{3 5}$ & $\mathbf{+ 1 7 \%}$ \\
\hline
\end{tabular}

Tabel 2. Rangkuman baku mutu air laut dari Kepmen LH 51, 2014.

Table 2. Resume of sea water quality standard from Decree of Ministry of Environment no. 51, 2004.

\begin{tabular}{ccccc}
\hline \multirow{2}{*}{ Parameter } & \multirow{2}{*}{ Satuan } & \multicolumn{3}{c}{ Kriteria Baku Mutu Air Laut } \\
\cline { 3 - 5 } & & Pelabuhan & Wisata Bahari & Biota Laut \\
\hline Suhu & ${ }^{0} \mathrm{C}$ & Alami & Alami & $28-32$ \\
Salinitas & $\mathrm{ppm}$ & alami & alami & $33-34$ \\
DO & $\mathrm{mg} / \mathrm{L}$ & - & $>5$ & $>5$ \\
BOD5 & $\mathrm{mg} / \mathrm{L}$ & - & 10 & 20 \\
TSS & $\mathrm{mg} / \mathrm{L}$ & 80 & 20 & 80 \\
\hline
\end{tabular}

